\title{
Settlement of Shallow Circular Foundations with Structural Skirts Resting on Sand
}

\author{
M.Y. Al-Aghbari \\ Dept. of Civil and Architectural Engineering, Sultan Qaboos University, P.O. Box 33, Al-Khoud 123, Muscat, Oman
}

Received 27 March 2005; accepted 10 April, 2006
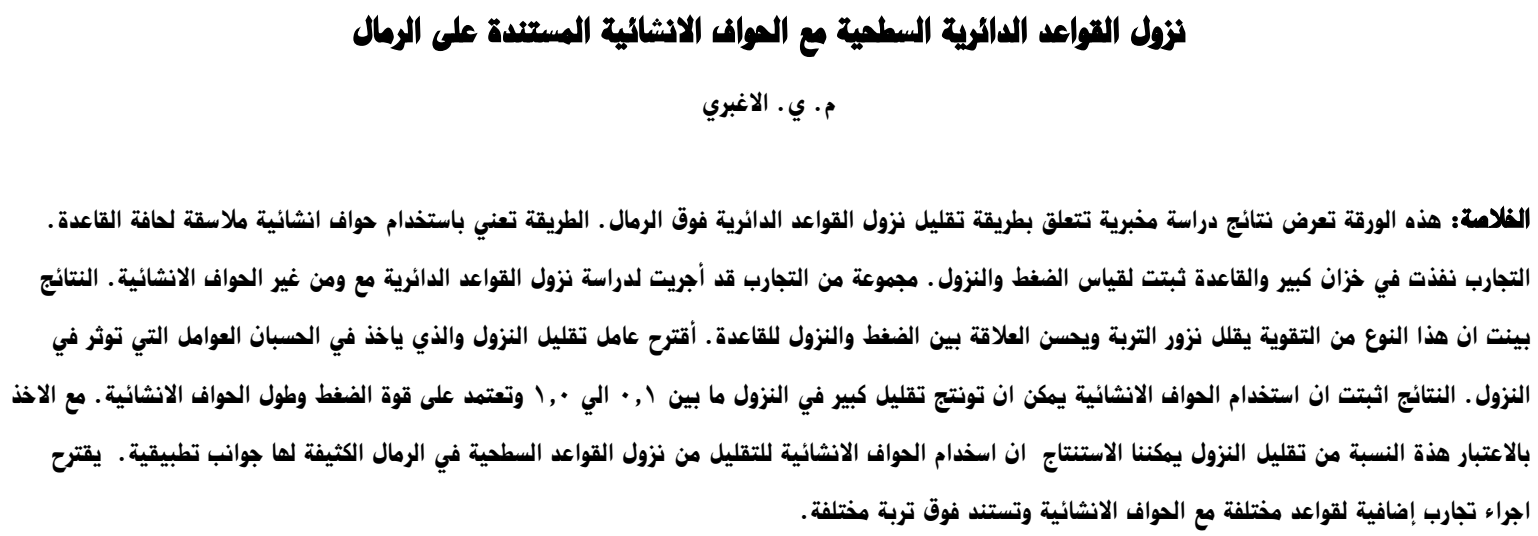

\begin{abstract}
This paper presents the findings of an experimental study concerning a method of reducing the settlement of shallow circular foundations on sand. It involves the use of structural skirts fixed to the edges of foundations. The experiments were performed in a large tank setting and the footing was instrumented in order to measure normal stresses and settlement. A series of tests were conducted to study the settlements of a circular footing with and without structural skirts. Test results indicate that this type of reinforcement reduces the settlement of subgrade and modifies the stress-displacement behaviour of the footing. A settlement Reduction Factor (SRF) was proposed, which takes into account the influence of various parameters that affect settlements. Results show that the use of structural skirts can produce enhanced settlement reduction in the range of 0.1 to 1.0 depending on stress applied and skirt depth. Given these levels of settlements reduction, it is concluded that the use of structural skirts to reduce the settlement of shallow foundations on dense sand is of practical significance. Further testing is recommended for different foundation shapes with structural skirts resting on different soil types.
\end{abstract}

Keywords: Structural skirts, Foundations, Settlement, Shallow, Circular, Sand

\section{Introduction}

Foundation design should satisfy two criteria; one deals with ultimate bearing capacity of the soil under the foundation and the other is concern with the limit of soil deformation. An excessive settlement, may induce a differential settlement, which causes structural distresses of the superstructure. Thus, it is required in many conditions to reduce the settlement to acceptable limits.

The improvement of the bearing capacity of subgrades and, hence, modifying the stress-strain relationship by utilization of horizontal reinforcement has been reported by Binquet and Lee (1975). They studied the effect of horizontal reinforcement of soils on the bearing capacity of

*Corresponding author’s e-mail: aghbari1@squ.edu.om foundations by conducting a series of experiments. Akinmusuru and Akinbolade (1981), Fragaszy and Lawton (1984), and Verma and Char (1986) have also contributed to this investigation with their experimental studies. Samtani and Sonpal (1989), and Mahmoud and Abdrabbo (1989) have studied the effect of vertical reinforcements of the soil on the bearing capacity of foundations. They conducted a series of tests, and concluded that the bearing capacity of a foundation can be increased to about one-and-a-half to two times that of the unreinforced soil. They also suggested this method for improving the bearing capacity of existing foundations.

Various methods of soil stabilization are known. However, they are sometimes prohibitively expensive and restricted by site specific conditions. In some cases they are difficult to apply to existing foundations. It is, there- 
fore, suggested that an alternative approach is required for improving the bearing capacity of soils and reducing the settlements. This approach is based on the use of "structural skirts" fixed to the edges of the foundation. This method of improvement does not require an excavation of the soil and, thus, it is not restricted by the presence of a high water table.

Structural skirts fixed to the edges of shallow foundations have been used for a considerable time, principally to increase the "effective depth" of the foundations in marine and other situations where water scours may be a problem. Bransby and Randolph (1998) have provided a valuable detailed consideration of their use in such applications. However, the use of such structural skirts in conjunction with conventional shallow structural foundations has not been widely employed, nor have the improvements in settlement resulting from their use been investigated in detail. On this basis, an experimental study was undertaken to establish the degree of improvement in settlements to be gained from increasing the effective depth of shallow foundations by fixing structural skirts to their edges.

In this paper, the background, methodology and findings of an experimental study of the settlement of shallow circular foundations with structural skirts on sand subjected to central vertical loads are presented. The various factors influencing the settlement improvements to be derived from the use of these skirts are identified. The benefits identified are combined into a parameter called Settlement Reduction Factor (SRF), and it is suggested that this parameter can be introduced into the settlement prediction equation for circular foundations resting on sand.

\section{Test Apparatus and Procedure}

An experimental investigation was carried out using a laboratory model. The experimental set-up consists of a rigid test tank, sand raining apparatus, a loading mechanism, an instrumented footing and a data acquisition system. The principal dimensions and layout of the apparatus are shown in Fig. 1.

The tank was $1000 \times 1000 \mathrm{~mm}$ in cross section and 800 $\mathrm{mm}$ in height. It was made of wood and was stiffened with steel frames. The circular footing was a metal plate that had a diameter of $120 \mathrm{~mm}$ and a thickness of $30 \mathrm{~mm}$. The tank was about 8 times the diameter of the footing and it was envisaged that there was no edge effects or that they would be minimal, if there any. The depth of the foundation was adjustable according to the requirement of the surcharge depth $\left(D_{f}\right)$. At the middle top of the foundation, a small recess was made for locating a metal ball for the application of the load. The ball allows the foundation to tilt.

The sand was placed in the tank by a sand raining technique. A special sand raining apparatus was designed to suit the tank size. This sand raining technique causes the

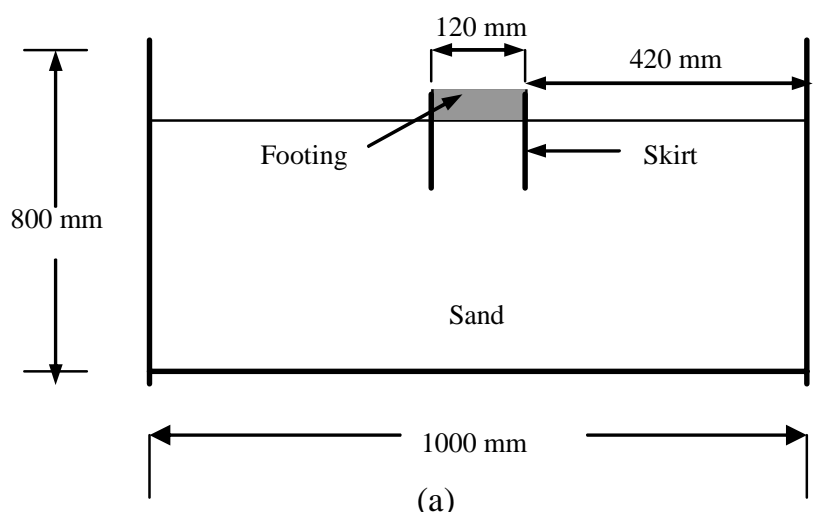

(a)

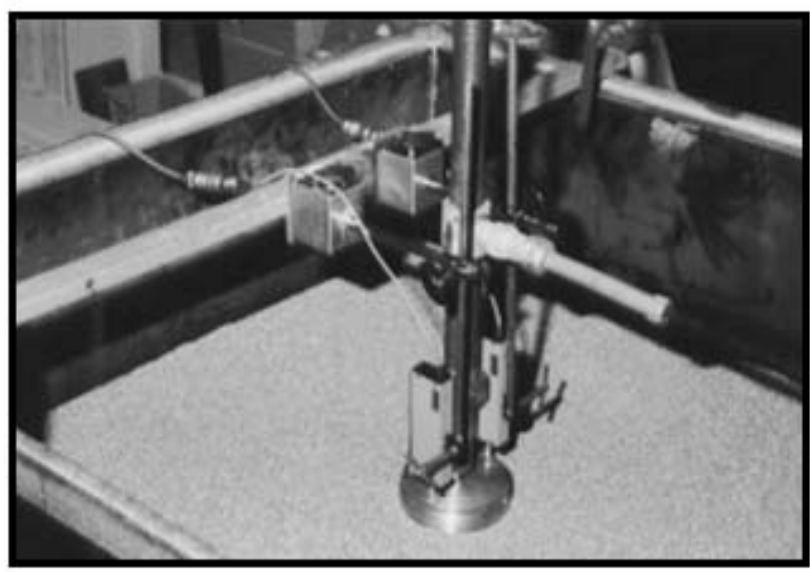

(b)

Figure 1. (a) Dimensions of testing tank and (b) Set-up of the loading celll and LVDTs on the footing

sand particles to fall on the whole bed area from a receptacle placed above the receiver tank (Butterfield and Andrawes, 1970). A range of densities could be obtained by altering the intensity and the height of fall of the sand. In order to eliminate the effect of the later, this distance was kept constant at $800 \mathrm{~mm}$ in order to achieve a constant density. Furthermore, a series of tests were carried out to check the uniformity of the sand bed using density pots, which were placed in various parts of the tank.

For the foundations with skirts, the skirts were placed first in a vertical position on the top of the pre-placed sand. After the skirts were placed in the tank, sand was deposited using the same procedure as outlined above. Then the sand raining was stopped, when the required sand level reached the level of foundation base. Finally, the surface of sand was levelled and the foundation was placed on top of the skirt.

The skirts comprised Stanley steel plates with a Modulus of Elasticity (E) of $210 \mathrm{kN} / \mathrm{mm}^{2}$. The thickness of the skirt was $6 \mathrm{~mm}$ and it was welded to form an open cylinder shape. The footing was placed on the top of the skirt.

The foundation was loaded by means of a motorized 10 ton capacity hydraulic jack at a constant rate of displace- 
ment of $12 \mathrm{~mm}$ per hour. The applied load was measured using a load cell of $10 \mathrm{kN}$ capacity placed on the top of the footing. Two LVDT transducers having a minimum resolution of $0.04 \mathrm{~mm}$ were placed at two different locations on top of the footing for measuring the settlement. The output voltage of each individual electrical measuring circuit was recorded automatically in one minute intervals using a data logging system.

\section{Material}

A coarse river sand was used throughout this experimental investigation. The particle size distribution of the sand is shown in Fig. 2. The sand has $\mathrm{D}_{10}, \mathrm{D}_{30}, \mathrm{D}_{60}$, and $\mathrm{D}_{50}$ vales of $0.45,0.65,0.85$ and $0.80 \mathrm{~mm}$, respectively. These yeild a coefficient of uniformity $\left(\mathrm{C}_{\mathrm{u}}\right)$ of 1.89 and a coefficient of curvature $\left(\mathrm{C}_{\mathrm{c}}\right)$ of 1.11. Thus the sand was uniform or poorly-graded. The unit weight of the sand in the tank was $16.5 \mathrm{kN} / \mathrm{m}^{3}$ and specific gravity was 2.65 .

In order to investigate the strength properties of the sand, triaxial tests were carried out to determine the angle of internal friction. The sand specimens were $38 \mathrm{~mm}$ in diameter and $76 \mathrm{~mm}$ high. Different values of confining pressures were used in the range 40 to $200 \mathrm{kN} / \mathrm{m}^{2}$. The samples preparation and test procedure were according to BS.1377:1990. The results showed that the average peak friction angle was $42^{\circ}$ for all ranges of confining pressures.

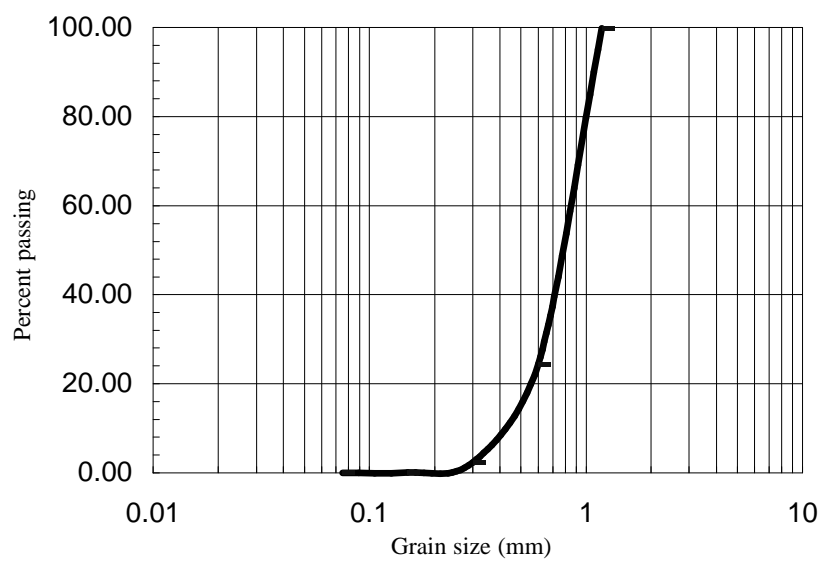

Figure 2. Grain size distribution of the sand

\section{Results of Tests without Structural Skirts}

In order to establish that the data from the tank test facilities were reproducible and in conformity with the findings of previous investigations, two tests were conducted on surface foundations $\left(D_{f} / B=0\right)$ without structural skirts and another two tests for shallow foundations $\left(D_{\mathrm{f}} / \mathrm{B}=0.5\right)$. In all cases, footings without structural skirts were tested. The stress-settlement ratio relationships for the tests are shown in Fig. 3. The settlement ratio is defined as the ratio between the settlement of the footing (S) to the footing width (B).The overall behaviour observed shows that the two tests for both footing depths gave similar results. For the same depth, the difference between the two tests was within $2 \%$. Therefore, the reproducibility of the test results was considered to be satisfactory. Thus, they may be used as the basis for determining the improvements to be derived from the use of structural skirts.

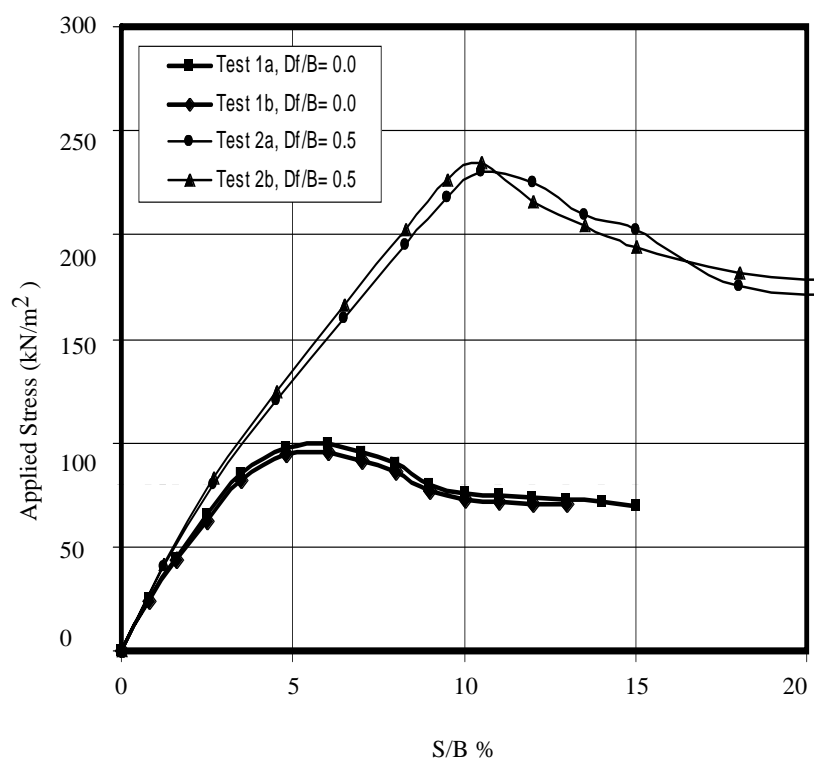

Figure 3. Stress-settlement relationship of tests without skirts

The results from the two surface footings tests were further analyzed and compared with the predicted values using some of the existing methods by Terzaghi and Peck (1967), Schmertmann (1970), Bazaraa (1967), and Meyerhof (1965). To predict the settlement of footing by these methods, the Standard Penetration Test $(\mathrm{N})$ value of the sand was required. The $\mathrm{N}$ value was determined using the relationship between angle of friction and $\mathrm{N}$-value proposed in the literature (Das, 1999). A comparison between the experimental settlement at values 0.5 peak load and theoretical predictions of a surface footing $\left(\mathrm{D}_{\mathrm{f}} / \mathrm{B}\right.$ $=0$ ) are presented in Table 1 .

Table 1. Comparison between calculated and measured values of settlement of 0.5 peak load of a surface footing
Method

Terzaghi and
Peck (1967)
Bazaraa (1967)
Schmertmann
(1970)
Meyerhof
(1965)

Settlement
$\begin{gathered}\text { Calculated, } S_{\text {cal }} \\ (\mathbf{m m})\end{gathered}$

0.16

0.71

0.22

0.25

1.13

0.84
Shallow foundations are generally designed with safety factors of 2-3 with respect to bearing capacity. A factor of safety of 2 implies $50 \%$ of the peak load and, hence, the 
0.5 peak load is used for comparing actual and calculated settlements.

It can be concluded that the Terzaghi and Peck method (1967) underestimates the settlement of the model footings. Similar results were also reported by Hanna and Abdel-Rahman (1987), and Ameen (1991). The methods proposed by Schmertmann's (1970) and Meyerhof (1965) overestimate the settlement, while the method proposed by Bazaraa (1967) gave the closest values to those obtained in this study.

Based on an extensive analysis of settlement results, Sivakugan et al. (1998) reported that the methods proposed by Terzaghi and Peck (1967) and Schmertmann (1970) overestimate the settlements by $218 \%$ and $339 \%$, respectively. As reported by Sivakugan and Johnson (2002, 2004), the scatter associated with the settlement prediction methods is quite high. They proposed a probabilistic approach to take this scatter into consideration.

\section{Results of Tests with Structural Skirts}

The second part of the test program involved the testing of the footing with structural skirts. Several experimental tests were carried out for different skirt depth ratios (Ds/B) of 0.05, 0.25, 0.5, 0.75, 1.0, 1.25 and 1.5. The stress-settlement relationships data obtained from these tests are shown in Fig. 4. Data were further analyzed and compared with the results obtained from the tests for a surface footing $\left(\mathrm{D}_{\mathrm{f}} / \mathrm{B}=0\right)$ and a shallow footing $\left(D_{\mathrm{f}} / \mathrm{B}=0.5\right)$ without the skirt. The settlement of the footing at a given stress with and without skirt, $S_{s}$ and $S_{f}$ respectively, was obtained from the stress-settlement relationship. The Settlement Reduction Factor (SRF), which is defined as $\mathrm{SRF}=S_{s} / S_{f}$, was used throughout this paper to assist in comparing the results.

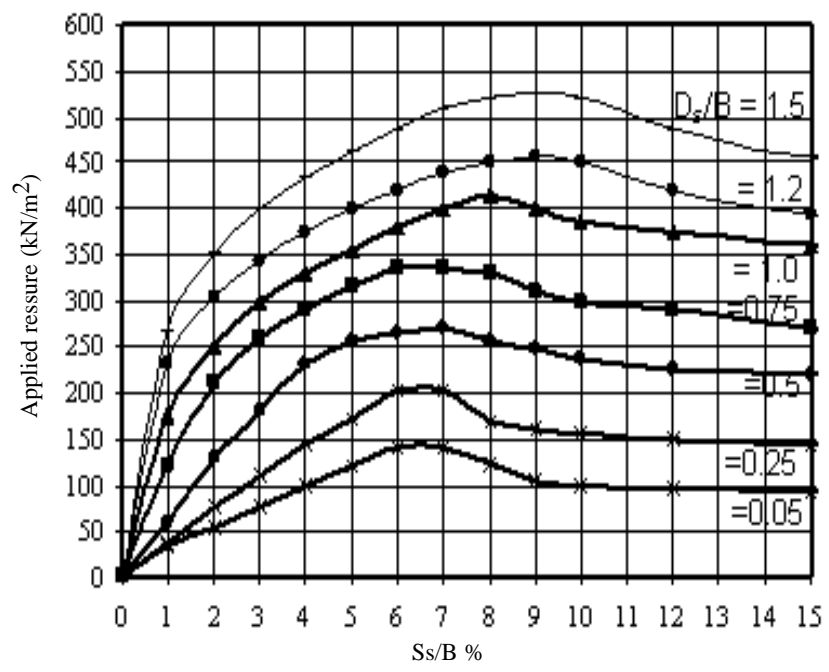

Figure 4. Stress-settlement relationship of tests with skirts

The tests results for a surface footing $\left(D_{\mathrm{f}} / \mathrm{B}=0\right)$ and a shallow footing $\left(\mathrm{D}_{\mathrm{f}} / \mathrm{B}=0.5\right)$ at different skirt depths are summarized in Tables 2 and 3, respectively. The compari-
Table 2. SRF for surface footing at different stress levels

\begin{tabular}{|c|c|c|c|c|c|}
\hline $\begin{array}{l}\text { Test } \\
\text { No. }\end{array}$ & Ds/B & $\begin{array}{l}\text { Stress } \\
\left(\mathbf{k N} / \mathbf{m}^{2}\right)\end{array}$ & $\mathbf{S}_{\mathrm{f}}$ & $\mathbf{S}_{\mathbf{S}}$ & SRF \\
\hline & & 25 & 0.7 & - & 1.00 \\
\hline \multirow[t]{4}{*}{$1 \mathrm{a}$} & 0 & 50 & 1.9 & - & 1.00 \\
\hline & & 75 & 3.0 & - & 1.00 \\
\hline & & 100 & 5.0 & - & 1.00 \\
\hline & & 25 & 0.7 & 0.65 & 0.92 \\
\hline \multirow[t]{4}{*}{3} & 0.05 & 50 & 1.9 & 1.70 & 0.89 \\
\hline & & 75 & 3.0 & 2.80 & 0.93 \\
\hline & & 100 & 5.0 & 4.20 & 0.84 \\
\hline & & 25 & 0.7 & 0.55 & 0.78 \\
\hline \multirow[t]{4}{*}{4} & 0.25 & 50 & 1.9 & 1.40 & 0.74 \\
\hline & & 75 & 3.0 & 2.00 & 0.67 \\
\hline & & 100 & 5.0 & 3.00 & 0.60 \\
\hline & & 25 & 0.7 & 0.45 & 0.64 \\
\hline \multirow[t]{4}{*}{5} & 0.5 & 50 & 1.9 & 0.90 & 0.47 \\
\hline & & 75 & 3.0 & 1.10 & 0.37 \\
\hline & & 100 & 5.0 & 1.80 & 0.36 \\
\hline & & 25 & 0.7 & 0.40 & 0.57 \\
\hline \multirow[t]{4}{*}{6} & 0.75 & 50 & 1.9 & 0.60 & 0.31 \\
\hline & & 75 & 3.0 & 0.70 & 0.23 \\
\hline & & 100 & 5.0 & 0.90 & 0.18 \\
\hline & & 25 & 0.7 & 0.30 & 0.43 \\
\hline \multirow[t]{4}{*}{7} & 1.0 & 50 & 1.9 & 0.40 & 0.21 \\
\hline & & 75 & 3.0 & 0.43 & 0.1 \\
\hline & & 100 & 5.0 & 0.60 & 0.12 \\
\hline & & 25 & 0.7 & 0.20 & 0.28 \\
\hline \multirow[t]{4}{*}{8} & 1.25 & 50 & 1.9 & 0.25 & 0.13 \\
\hline & & 75 & 3.0 & 0.30 & 0.1 \\
\hline & & 100 & 5.0 & 0.50 & 0.10 \\
\hline & & 25 & 0.7 & 0.13 & 0.18 \\
\hline \multirow[t]{3}{*}{9} & 1.5 & 50 & 1.9 & 0.20 & 0.11 \\
\hline & & 75 & 3.0 & 0.22 & 0.07 \\
\hline & & 100 & 5.0 & 0.32 & 0.0 \\
\hline
\end{tabular}

son of settlement for a footing with and without skirt is made for different stress levels at the peak load.

From the comparisons given in the Tables 2 and 3, it is clear that structural skirts have a significant influence on the reduction of footing settlement at surface and shallow depths. The results show that for a given depth of a skirt, the reduction factor generally decreases as the stress increases. This is because of non-linearity of the stressstrain relationship of the soil (see Figs. 3 and 4). In Fig. 3 , the footing without skirts curved more to the right for higher stresses while the curves for footing with skirts (Fig. 4) were less curved and they were more in the elastic range.

Using a regression analysis with a coefficient of correlation $\mathrm{R}^{2}=0.95$, an equation was proposed to calculate the settlement reduction factor (SRF) as:

$$
\mathrm{SRF}=\mathrm{e}^{\left(-0.18 \frac{\mathrm{D}_{\mathrm{S}}}{\mathrm{B}} \sqrt{\sigma}\right)}
$$

where

Ds/B : skirt depth ratio

$\sigma \quad$ : stress applied on the footing 
Table 3. SRF for shallow footing $\left(D_{\mathrm{f}} / \mathrm{B}=0.5\right)$ at different stress levels

\begin{tabular}{|c|c|c|c|c|c|}
\hline $\begin{array}{l}\text { Test } \\
\text { No. }\end{array}$ & Ds/B & $\begin{array}{l}\text { Stress } \\
\left(\mathbf{k N} / \mathbf{m}^{2}\right)\end{array}$ & $\mathrm{S}_{\mathrm{f}}$ & $\mathrm{S}_{\mathrm{S}}$ & SRF \\
\hline \multirow{7}{*}{2} & \multirow{8}{*}{0} & 025 & 0.80 & - & 1 \\
\hline & & 050 & 1.50 & - & 1 \\
\hline & & 075 & 2.30 & - & 1 \\
\hline & & 100 & 3.50 & - & 1 \\
\hline & & 150 & 5.50 & - & 1 \\
\hline & & 175 & 6.00 & - & 1 \\
\hline & & 200 & 6.50 & - & 1 \\
\hline \multirow{9}{*}{5} & & 230 & 7.00 & - & 1 \\
\hline & \multirow{8}{*}{0.5} & 025 & 0.80 & 0.45 & 0.56 \\
\hline & & 050 & 1.50 & 0.70 & 0.47 \\
\hline & & 075 & 2.30 & 1.10 & 0.47 \\
\hline & & 100 & 3.50 & 1.50 & 0.42 \\
\hline & & 150 & 5.50 & 2.00 & 0.36 \\
\hline & & 175 & 6.00 & 2.20 & 0.36 \\
\hline & & 200 & 6.50 & 2.40 & 0.37 \\
\hline & & 230 & 7.00 & 2.60 & 0.37 \\
\hline \multirow{7}{*}{6} & \multirow{8}{*}{0.75} & 025 & 0.80 & 0.40 & 0.50 \\
\hline & & 050 & 1.50 & 0.50 & 0.33 \\
\hline & & 075 & 2.30 & 0.60 & 0.26 \\
\hline & & 100 & 3.50 & 0.60 & 0.17 \\
\hline & & 150 & 5.50 & 1.20 & 0.22 \\
\hline & & 175 & 6.00 & 1.80 & 0.30 \\
\hline & & 200 & 6.50 & 1.80 & 0.27 \\
\hline \multirow{9}{*}{7} & & 230 & 7.00 & 2.00 & 0.28 \\
\hline & \multirow{8}{*}{1.0} & 025 & 0.80 & 0.30 & 0.38 \\
\hline & & 050 & 1.50 & 0.40 & 0.27 \\
\hline & & 075 & 2.30 & 0.43 & 0.19 \\
\hline & & 100 & 3.50 & 0.45 & 0.13 \\
\hline & & 150 & 5.50 & 0.70 & 0.13 \\
\hline & & 175 & 6.00 & 1.00 & 0.17 \\
\hline & & 200 & 6.50 & 1.20 & 0.18 \\
\hline & & 230 & 7.00 & 1.50 & 0.21 \\
\hline \multirow{7}{*}{8} & \multirow{7}{*}{1.25} & 025 & 0.80 & 0.20 & 0.25 \\
\hline & & 050 & 1.50 & 0.25 & 0.17 \\
\hline & & 075 & 2.30 & 0.28 & 0.12 \\
\hline & & 100 & 3.50 & 0.30 & 0.08 \\
\hline & & 150 & 5.50 & 0.50 & 0.09 \\
\hline & & 175 & 6.00 & 0.70 & 0.11 \\
\hline & & 200 & 6.50 & 0.90 & 0.14 \\
\hline \multirow{9}{*}{9} & \multirow{9}{*}{1.50} & 230 & 7.00 & 1.00 & 0.14 \\
\hline & & 025 & 0.80 & 0.13 & 0.16 \\
\hline & & 050 & 1.50 & 0.20 & 0.13 \\
\hline & & 075 & 2.30 & 0.22 & 0.10 \\
\hline & & 100 & 3.50 & 0.32 & 0.09 \\
\hline & & 150 & 5.50 & 0.40 & 0.07 \\
\hline & & 175 & 6.00 & 0.60 & 0.10 \\
\hline & & 200 & 6.50 & 0.70 & 0.11 \\
\hline & & 230 & 7.00 & 0.80 & 0.08 \\
\hline
\end{tabular}

A comparison between the proposed Equation and the experimental results was made and the results are shown in Fig. 5. It is clear that the proposed equation is consistent with the experimental results and thus, it can be used to estimate the Settlement Reduction Factor (SRF) of footings with skirts.

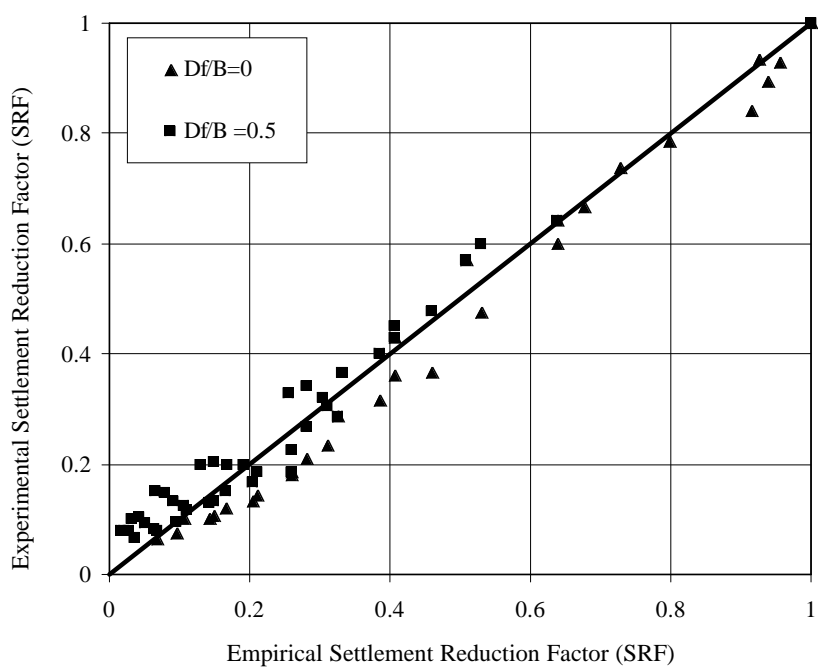

Figure 5. Relationship between the proposed empirical SRF and the experimental SRF

\section{Conclusions and Recommendations}

- Test results indicate that the use of structural skirts reduces the settlement of footings and modifies the load-displacement behaviour.

- The Terzaghi and Peck Method underestimates the settlement significantly by about $30 \%$.

- A simple linear equation is proposed to estimate the Settlement Reduction Factor. The experimental results have a good correlation with the proposed equation.

- Further investigations are recommended for different foundation shapes with structural skirts resting on different soil types.

\section{References}

Akinmusure, J.O. and Akinbolade, J.A., 1981, "Stability of Loaded Footings on Reinforced Soil," J. of Geotechnical Engineering Division, American Society of Civil Engineering, Vol. 107(GT6), pp. 819827.

Ameen, S. F., 1991, "Settlement of Inclined Loaded Footings on Sand Layers," Proceedings of the 9th Asian Regional Conference on Soil, pp. 197-200.

Bazaraa, A.R., 1967, "Use of the Standard Penetration Test for Estimating Settlements of Shallow Foundations on Sand," Ph.D. Thesis, University of Illinois, USA.

Binquet, J. and Lee, K. L., 1975, "Bearing Capacity Analysis of Reinforced Earth Slabs," J. of Geotechnical Engineering Division, American Society of Civil Engineering, Vol. 101(GT12), pp. 1257-1275.

Bransby, M.F. and Randolph, M.F., 1998, Combined Loading of Skirted Foundation," Geotechnique, Vol. 48(5), pp. 637-655.

British Standard 1377, 1990, Method of Test for Soils for 
Civil Engineering Purposes, British Standard Institution, London.

Butterfield, R. and Andrawes, K.Z., 1970, “An Air Activated Sand Spreader for Forming Uniform Sand Beds," Geotechnique, Vol. 20(1), pp. 97100.

Das, P. M., 1999, "Principles of Foundation Engineering. Fourth Edition," PWS Publishing.

Fragaszy, R.J. and Lawton, E., 1984, "Bearing Capacity of Reinforced Sand Subgrades," J. of Geotechnical Engineering Division, American Society of Civil Engineering, Vol. 110(10), pp. 1500 - 1507.

Hanna, A..M. and Abdel-Rahman, M., 1987, "Experimental Evaluation of Foundation Settlement in Sand," Proc. Int. Conf. Foundations and Tunnels, University of London, Vol. 1, pp. 34-37.

Mahmoud, M.A and Abdrabbo, F.M., 1989, "Bearing Capacity on Strip Footing Resting on Reinforced Sand Subgrades," Canadian Geotechical Journal, Vol. 26, pp. 154159.

Meyerhof, G.G., 1965, "Shallow Foundations," J. of Soil Mechanics and Foundation Engineering, ASCE, Vol. 91( SM2), pp. 21-31.

Samtani, N.C. and Sonpal, R.C., 1989, "Laboratory Tests of Strip Footing on Reinforced Cohesive Soil," J. of
Geotechnical Engineering Division, ASCE, Vol. 115(9), pp. 1326-1330.

Schmertmann, J.H., 1970, "Static Cone to Compute Static Settlement Over Sand," J. of Soil Mechanics and Foundation Engineering, ASCE, Vol. 96(SE3), pp. 1011-1043.

Sivakugan, N., Eckersley, J.D. and Li, H., 1998, "Settlement Predictions using Neural Networks," Australian Civil Engineering Transactions, CE 40, pp. 49-52.

Sivakugan, N. and Johnson, K., 2002, "Probabilistic Design Chart for Settlements of Shallow Foundations in Granular Soils," Australian Civil Engineering Transactions, CE 43, pp. 19-24.

Sivakugan, N. and Johnson, K., 2004, "Settlement Predictions in Granular Soils: A Probabilistic Approach," Geotechnique, Vol. 54(7), pp. 499-502.

Terzaghi, K. and Peck, R.B., 1967, "Soil Mechanics in Engineering Practice," John Wiley and Son Inc.

Verma, B.P. and Char, A.N.R., 1986, "Bearing Capacity Test on Reinforced Sand Subgrades," J. Geotechnical Engineering Division, ASCE, Vol. 112(7), pp. 701706. 